\title{
Un Punto entre Cero: el Tema del Tiempo en Trilce
}

Trilce fue menos una revolución en el arte de Vallejo que un desarrollo de tendencias nacientes en la fértil experimentación de Los beraldos negros. Por supuesto, los primeros versos de Los beraldos negros, derivados del Modernismo, distan de la poesía radical y entrañablemente original de Trilce. Pero la evolución ya se había iniciado en la primera obra de Vallejo y, además, ésta fue una metamorfosis más bien estilistica que temática: evolución que no destronó ideas e ideales antiguos, sino que los encarnó en nuevas formas. Trilce fue un esfuerzo esencialmente conservador; Vallejo intentó expresar, en la continua temática de su angustia, Ia continuidad de su yo presente con su yo pasado. Evolución proustiana, diríamos, producto de un hombre aterrado por la posibilidad de ver su yo pasado convertirse en yo extranjero. Tal angustia temporal no sólo crea el tema principal de la obra, sino también inspira los estratos intactos que perduran bajo el flujo del estilo. Por lo tanto, este ensayo empieza con un breve resumen de la continuidad evolutiva de Los beraldos negros y Trilce.

Los primeros poemas de Vallejo fueron descripciones de paisajes, escritos bajo la influencia del Modernismo. "Aldeana", el primer poema terminado para Los beraldos negros, es evidentemente la descripción de algún paisaje campestre:

Lejana vibración de esquilas mustias,

en el aire derrama

la fragancia rural de sus angustias.

En el patio silente

Sangra su despedida el sol poniente.

El ámbar otoñal del panorama

toma un frío matiz de gris doliente!1

1 Toda cita es de las siguientes ediciones de las obras de Vallejo:

Vallejo, César. Los beraldos negros. Lima, 1959.

-2.. Trilce. Bueros Aires, 1961. 
Las tres frases de la estrofa empiezan con datos físicos de la campiña, que presenciamos juntos con el poeta. Oímos un sonido ("vibración de esquilas"), vemos un lugar ("patio silente"), y un color ("ám. bar otoñal"). Sin embargo, el poeta juvenil engalana estos meros hechos con adjetivos e imágenes que los visten de un aura de angustia retórica. Así las esquilas padecen "angustias" y son "mustias". Así el sol "sangra" en el patio, y el "ámbar otoñal" se transforma en un "gris doliente". La angustia, la sangre y el dolor transforman el paisaje en el correlativo de la sensibilidad del poeta.

Basándose en esta temprana tendencia de Vallejo a poetizar paisajes, algunos críticos le han bautizado de vate autóctono de Perú. Tales esfuerzos de convertir su poesía en canto indígena pasan por alto el hecho de que, aun en sus momentos más costumbristas, las palabras indias y el paisaje indígena sirven de vehículo para una visión personal, de manera que el Perú objetivo se transforma en un Perú subjetivo y universal. No cabe duda de que Vallejo habla de su yo, de su sangre india, cuando habla de Cuzco y de las montañas. Pero luego la fusión del yo con el paisaje pasará a segundo plano. Aun cuando el poeta joven escribió sus primeras líneas se sentía desarraigado de su sangre y su tierra, de su madre. El color local de su poesía palidece mientras que la subjetividad elabora un vehículo cada vez más sobrio, abstracto, e incoloro para su angustia, hasta presentarla en un claroscuro universal.

Poemas como "Aldeana", "Nostalgias imperiales", "Terceto autóctono", y "Bajo los álamos", que son descripciones de paisaje en primer plano, contienen estructuras temáticas dictadas por el mundo exterior. Claro que el poeta libremente escoge los elementos de su ambiente que organizará en pais poético, pero obedece a las severas demandas de los hechos y a las leyes de la naturaleza. En tal arte paisajista el poeta está presente como tenue niebla afectiva, enroscándose alrededor de objetos concretos. De forma típica estos poemas se convierten en metáforas efímeras, como, por ejemplo, en la tercera de las "Nostalgias imperiales":

Como viejos curacas van los bueyes camino de Trujillo, meditando... $Y$ al hierro de la tarde, fingen reyes que por muertos dominios van llorando.

Los bueyes no meditan: suponemos que el poeta ha proyectado sus sentimientos sobre la pantalla de la naturaleza.. ¿Y sobre qué meditan 
estos mamíferos? Lo sabemos cuatro renglones más abajo: lamentan muertos dominios. Estos datos son específicos, sin duda, pero las huidizas nostalgias que evocan empañan la escena con una niebla de vaguedad.

Muy pronto Vallejo abandonó sus melancólicos paisajes, que se pueden atribuir a la influencia de Darío, y sobre todo, de Herrera $y$ Reissig. Luego emplea el proceso inverso para satisfacer a las mismas necesidades subjetivas: en vez de comenzar con el paisaje y proceder del sentimiento, empieza con reflexiones emocionales y busca las imágenes, la concretización que será su perfecta expresión. En muchos casos, la distinción que acabamos de proponer parece deshacerse. Por ejemplo, "Las piedras" tiene como fondo un elemento de paisaje. Pero un paisaje, por definición, abarca cierta extensión, y en este poema los únicos elementos de paisaje que tenemos son las numerosas piedras. Luego, éste es menos un paisaje que un objeto concreto elevado, por multiplicación, encantación y aislamiento, a la expresión intensa de los senti. mientos del poeta: alma cuajada en hechos. Como Ios bueyes de "Terceto autóctono", las piedras incorporan el estado afectivo de Vallejo. Estas piedras están contaminadas de la angustia vital, de la vitalidad creadora que las produjo: se mueven, hablan, y sufren como entes de pesadilla. Cual Orfeo conmovido, Vallejo mueve las piedras con su arte. Son piedras interiores, y por consiguiente, piedras humanizadas.

En nuestro mundo objetivo, ¿qué podría ser una caravana de piedras azules? Nos recuerdan la pintura surrealista con sus telas casi deshabitadas, sólo pobladas por unos pocos objetos significativos, deformados por el pensamiento. En efecto, la trayectoria poética de Vallejo empieza con el equivalente verbal del arte impresionista para irse cambiando en aproximación a las pinturas de Dalí e Ives Tanguy. En Trilce aumenta el desapego de Vallejo frente a la lógica y las reglas geométricas y físicas que gobiernan el mundo que vemos; en Trilice la mezcla de metáforas es casi absurda. Por ejemplo:
El cancerbero cuatro veces
el día maneja su candado, abriéndonos
cerrándonos los esternones, en guiños
que entendemos perfectamente. (L)

Cualquier lector que intente imaginar este capricho (un cancerbero abriendo y cerrando esternones, y guiñando entre tanto) será tentado de risa. Aquí, así como en muchos poemas de Vallejo, la incongruencia 
es el producto de un tiempo y de una geografía interiores que ignoran al mundo regido por las leyes de la naturaleza. Como el Surrealismo, esto es menos físico que psicología; el foco indispensable de organización es el pensamiento del poeta. Por ejemplo, tal lógica interna (que escapa a la lógica objetiva) crea el orden de "Los heraldos negros": Vällejo escribe "golpes, resaca, zanjas, potros, atiles, heraldos, Cristos, pan", etc. Tenemos que imaginar y descifrar los procesos mentales del poeta si hemos de comprender tal mezcla verbal. Es una poesía que trata menos del mundo externo adornado con sentimientos, que con la extructura interna del sentimiento. El paisaje exterior se cambia en paisaje cerebral, espacio vital. Si el romanticismo consiste en la expresión de una subjetividad íntima, Vallejo es el más romántico de los poetas.

Esta tendencia centrípeta de los últimos poemas de Los beraldos negros es aún más característica de Trilce. Es un movimiento hacia adentro verdaderamente original, porque ignora el significado común de las palabras y los usos comunes de la expresión poética. Por supuesto, todo poeta inventa sa lenguaje privado. En efecto, se puede definir la literatura como un lenguaje que da énfasis a un significado dentro del contexto de la obra de arte, en vez de un significado en cuanto a las realidades exteriores. Northrop Frye postula que la definición de la literatura es centrípeta. Mas, para evitar la discusión de este problema teórico, complejo y extenso, supondremos que el lenguaje poético de Vallejo es más privado que el de muchos otros poetas: es tan elíptico, tan singular en Trilce que no divulga ni el primer nivel de significación con una sola lectura, o dos, o tres... En sus poemas postreros Vallejo usa palabras concretas, pero solamente para dar densidad de mundo a abstracciones, sentimientos y pensamientos, de manera que sea imposible comprender los versos al nivel concreto. En el poema número I de Trilce, por ejemplo, las islas y el guano son muchísimo más que simples elementos de algún paisaje sudamericano. Estos objetos son el "correlativo subjetivo" del estado psíquico del poeta: son emblemas de VaIlejo.

La originalidad de Trilice va más lejos, puesto que Vallejo no hace caso del impresionante acopio de símbolos que nos quedan como herencia de la literatura occidental. En otras palabras, la literatura puede considerarse como meta-lengua, formada por los significados convenidos de muchos símbolos dependientes del contexto geográfico y temporal: la rosa es símbolo de la belleza mística en el Paradiso de Dante; en la época romántica lo era de pasión. Generalmente los poetas hacen suyos estos niveles secundarios del lenguaje acumulados en los vastos alma- 
cenes de la tradición simbólica occidental. Cuando la luna brilla en la poesia de Vallejo no es la casta Diana que está sobreviviendo hasta en los versos radicales de Laforgue. Trilce, así como la obra de Mallarmé, eleva el lenguaje de la tribu a un nuevo significado.

Puesto que el lector no puede comprender inmediatamente el simbolismo emblemático de Vallejo, el crítico que quiera ponerlo en claro tiene que tratar esta poesía como si fuese cifrada. Nos da un pensamiento interiormente organizado, imágenes y motivos recurrentes, y un vocabulario, y tenemos que descifrar la maraña sin recurso externo. Dado el significado cifrado de la obra, no podemos limitarnos a un análisis del poema individual: tenemos que forrajear en la obra entera para descubrir el contexto que devolverá su pleno significado al simbolismo. Este contexto falta, o escasea, en el poema individual.

Par2 demostrar, aventuraremos un análisis estrictamente interno de uno de los poemas menos formidables de Trilce, el número XIX.

A trastear, Hélpide dulce, escampas, cómo quedamos de tan quedarnos.

Hoy viernes apenas me he levantado.

El establo está divinamente meado

y excrementido por la vaca inocente

y el inocente asno y el gallo inocente.

Penetra en la maría ecuménica.

Oh sangabriel, haz que conciba el alma, el sin luz amor, el sin cielo, lo más piedra, lo más nada. hasta la ilusión monarca.

Quemaremos todas las naves!

Quemaremos la última esencia!

Mas si se ha de sufrir de mito a mito, y a hablarme llegas masticando hielo, mastiquemos brasas, ya no hay dónde bajar, ya no hay dónde subir.

Se ha puesto el gallo incierto, hombre. 
La idea de conflicto domina sobre todo en los últimos seis versos; la oposición de hielo y brasas, de bajar y subir, crea y explica la incertidumbre del último verso. Es la incertidumbre de un gallo. Pero, gracias a una ambigüedad que sospechamos premeditada, el "hombre" se puede interpretar como caso vocativo, o, mejor, como parte de una serie que empieza con "incierto", de forma que la incertidumbre ha hecho del gallo un hombre. Parece que lo esencial del hombre es la incertidumbre, y que cualquier bestia, siendo indecisa, puede participar de esta esencia.

Ahora podemos proceder a un tosco esbozo del tema de este poema: La vida con que nos enfrentamos, como el nuevo día, es posibilidad; pero el hombre no puede saludar la mañana con la inocencia del gallo, y sólo acepta el futuro como "sufrimiento de mito a mito." La segunda y la tercera estrofa corroboran la posibilidad de que el poema esté explorando la tensión entre inocencia y experiencia. Los inocentes brutos, sumidos en sus cuerpos, sin mente, son alabados por Vallejo; hasta alaba sus excrementos, con intensidad irónica... Es una apoteosis del estiércol. No se puede evitar el aura de Natividad naturalista. Como la mañana, la situación hace frente al futuro. Sin embargo, la irrupción de lo divino en la tierra, la aparición de "sangabriel" anunciando la encarnación de Cristo y la deificación de toda la tierra (hasta el estiércol) no es más que una atormentada súplica. El poeta anhela una metamorfosis total - de toda la frialdad humana en amor, de la tierra en cielo, de la piedra (lo necesario) en lo imposible, de la nada en algo, de la ilusión en realidad - pero su deseo es un grito arrancado de la imposibilidad misma de lo que pide. Quemará todas las naves, todas las iglesias, y en este naufragio de la fe destruirá hasta la última esencia, Dios, porque el evangelio no es más que un mito entre mitos, parábolas e ilusiones que no pueden aliviar su pena. Concluimos que la duda - tragedia del conocimiento- convierte en hombre al bruto inocente. Vallejo da realce a lo negativo. La única alternativa que nos propone al sufrimiento y a la duda humanos es la calma de las vacas, el cerebro de un pájaro, y la divinidad del excremento. Vallejo une posibilidades opuestas en su propio ser. No nos debe extrañar la tensión de este poema: es un diálogo del cuerpo con el alma.

Nuestro análisis no ha sido cabal, pero hasta su exigua profundidad ha necesitado una trémula superestructura de especulación. Y todavía no hemos considerado muchas imágenes del poema inexpugnables en lo privado de su significación. ¿Por qué escribe "piedra, hielo, brazas?" Podríamos arriesgar alguna hipótesis, sin duda, pero no podríamos darle mucho peso, porque hundiría el tambaleante andamiaje de nuestra expli- 
cación. Este ensayo supone que hasta los poemas de Trilce que se dejan penetrar por el intelecto crítico con facilidad relativa no entregan la plenitud de su significado fuera de su contexto, y que los poemas más turbios (número I, por ejempo) son esencialmente incomprensibles si se estudian aislados. Trilce, si se ha de analizar adecuadamente, debe considerarse como un poema, y no setenta y seis.

Tal poesía crea nuevos nombres en el mundo, e impone al crítico la necesidad de aprender un nuevo idioma si ha de comprender sus elementos. La repetición de conceptos e imágenes que hace posible tal es. tudio indica también la unidad radical de la obra, que se puede considerar en su totalidad como una exploración del tiempo. Otros temas y motivos tienen su importancia para el poeta - la madre, el amor carnal, etc- - pero el tema obsesivo del tiempo es el principio central y organizador de Trilce. En lo siguiente trataremos de demostrar la importancia estructural de este tema, creando una gramática básica de los motivos de Trilce.

\section{EL PRESENTE}

De vez en cuando Vallejo nos advierte que debemos amar al presente:

Amémonos los vivos a los vivos, que las buenas cosas muertas será después. Cuánto tenemos que quererlas y estrecharlas, cuánto. Amemos las actualidades, que siempre no estaremos como estamos. (LXX)

Pero, el mandato de amar al presente está contagiado de angustia. Este tema (carpe diem) es producto de conciencia de la muerte. Debemos gozar de lo que tenemos, porque pronto tendremos menos.

En Trilce es difícil saborear el presente, porque tal gozo es atributo de los animales. Lo vemos en el poema LXI, cuando el poeta vuelve a la casa de su niñez, actualmente vacía, y llora. En contraste irónico, su caballo "dice que está bien, que todo está muy bien". Es la conciencia del pasado lo que causa la angustia de Vallejo; su caballo, existiendo en el presente, está muy bien. (Recordemos la vaca inocente, el asno inocente y el gallo inocente del poema XIX.) El hombre, siendo animal y conciencia a la vez, encuentra que la extirpación de su mente es muy dificil, a pesar de su ardicnte desco de hacerse carne bruta. Dado que la conciencia del pasado es un atormentado sentido de la progresiva 
muerte, Vallejo goza de las pocas veces que se deja llevar en la plácida corriente temporal de la conciencia animal:

Pienso en tu sexo.

Simplificado el corazón, pienso en tu sexo.

ante el hijar maduro del día.

Palpo el botón de dicha, está en sazón.

$\mathrm{Y}$ muere un sentimiento antiguo

degenerado en seso...

Oh conciencia, pienso, sí, en el bruto libre

que goza donde quiere, donde puede. (XIII)

Según parece, el pensamiento basta para hacer palpable el erotismo, y así, para hacer feliz al poeta en su nueva simplicidad y en la afortunada muerte de sus recuerdos. El erotismo sumerge la mente en las sensaciones del presente a tal grado que nada queda fuera de esa conmoción. Sin embargo, esta simplificación del corazón tiene que fallar en la poesía de Vallejo. El poema repite ("pienso... pienso") ideas del sentimiento, ideas del bruto subyugado por su carne. El pensaniento mismo sitúa al poeta a una distancia crítica del pulso del presente: ya ha capitulado a la razón. Y lo racional, por definición, incluye una doblez que no es sencillez, una reflexión que suplanta a lo inmediato. Así, el poema contiene menos brutalidad que deseo de identificarse con el bruto que conjura. La poesía, ipso facto, nace a una cierta distancia de la espontaneidad del presente. Es un sentimiento antiguo recordado en tranquilidad, como dijo Wordsworth. El pocta que trata de lo erótico y pretende estar empapado de sexo tiene que dejar seca una parte de su mente. El poeta, en cuanto poeta, refleja los amores de su pasado.

La naturaleza dual del hombre, que es animal y mente, es una doble desventaja. La atormentada meditación sobre el pasado sólo se alivia por breves treguas de animalidad. Pero recíprocamente, la conciencia está encadenada a una inescapable naturaleza corpórea. El símbolo tradicional para el cuerpo en tales casos, una cárcel, también se asocia a la existencia corpórea en Vallejo. El número cuatro, el número de paredes precisas para encarcelar el cuerpo humano en las tres dimensiones del espacio, recurre en Trilce y muchas veces desempeña exactamente esta función. El poema XVIII es el ejemplo más notable. Aunque trata de un acontecimiento específico, está construido de tal manera que alcanza un sentido simbólico; la limịitación de la existençia, 
Oh las cuatro paredes de la celda.

Ah las cuatro paredes albicantes

que sin remedio dan al mismo número.

Esta es limitación física. Pero más adelante en el poema, por un proceso típico de Vallejo, el símbolo abarca la esfera de la conciencia:

Ah las paredes de la celda.

De ellas me duele entretanto más

las dos largas que tienen esta noche

algo de madres que ya muertas

llevan por bromurados declives,

a un niño de la mano cada una.

¿Qué son las paredes? Suponemos que todavía representan el encierro, como en la primera estrofa. Pero ahora los confines deben ser más simbólicos que concretos; dos paredes no pueden encarcelar a un hombre. ¿Y por qué "duelen más"?

Encontramos guías en otros problemas. Por ejemplo, Vallejo se dirige a los muertos en el poema LXXV:

Eståis muertos

Qué extraña manera de estarse muertos. Quienquiera diría no lo estáis. Pero, en verdad, estáis muertos.

Flotáis nadamente detrás de aquesa membrana que, péndula del zenit al nadir, viene y va de crepúsculo a crepúsculo, vibrando ante la sonora caja de una herida que a vosotros no os duele.

Parece que la membrana es una cortina, y que el presente se cambia en pasado, pasando detrás de ella. Es el filo del tiempo que avanza y que, de forma característica, Vallejo asocia al dolor. Los muertos que pasan al pasado están presentes "nadamente", pero hasta la presencia negativa de 12 muerte es tan ineluctable, tan terrible, que la mente presente y viviente no puede pensar en otra cosa y se llena de nada: "os digo, pues, que la vida está en el espejo, y que vosotros sois el original, la muerte". (LXXV) Imaginamos: la membrana ha sido pulida; es la mente reflexiva del hombre y el presente se compone de puntos de 
tiempo tan fugaces que no existen, como los puntos de planos matemáticos. La terrible fragilidad del presente es doblemente obvia cuando hace frente a las largas visitas del pasado, que contienen infinitos recuerdos. En efecto, el presente no puede contener nada, siendo demasiado estrecho. Pero el pasado tiene la extensión necesaria para acomodar las dimensiones de la existencia. En suma, el presente es un plano (una pared, una membrana), y el pasado es un volumen temporal; paradójicamente, la existencia es solamente posible dentro de la amplitud de la muerte. Vallejo, expresando las dimensiones del tiempo por imágenes espaciales concretas, nos ha dado una brillante exposición del problema proustiano: ¿cómo puede un hombre, consciente de que la vida es una muerta progresiva, entablar una continuidad vital con el pasado?

El futuro tiene su volumen y también su membrana. El poema XL trata de la idea del futuro de un niño, imaginada desde el punto de vista del poeta. Vallejo escribe:

Entonces, ni el propio revés de la pantalla deshabitada enjugaría las arterias trasdoseadas de dobles todavías.

Como si no hubiesen dejado salir! Como si no estuviésemos embrazados siempre a los dos flancos diarios de la fatalidad!

Primero, nos damos cuenta de que en este poema la pantalla hace cara al futuro. La palabra "deshabitada" es una guía, puesto que el pasado está más habitado que el presente en la poesía de Vallejo. ${ }^{2}$ Es significativo el hecho de que el hombre cree que los niños no reconocen su encarcelamiento; que todavía piensan que les dejarán salir. Pcro están atrapados entre los dos flancos de la diaria fatalidad, insertos entre el pasado inaccesible y el futuro también inaccesible, porque no existe. Cuatro paredes encarcelan a un hombre en el espacio, dos bastan para atraparle en el tiempo. Las últimas estrofas del poema XVIII probablemente tienen que ver con este concepto. El poeta está emparedado temporalmente:

Ah las paredes de la celda.

De ellas me duele entretanto más

2 En Trilce, el futuro se califica en términos de vacuidad, de aniquilación. Mas, las palabras "frente" y "frontal" aparecen en otra parte del poema. En la espacialización tan característica del tiempo de Vallejo: el futuro está enfrente $y$ lo posterior es el pasado. 
las dos largas que tienen esta noche algo de madres que ya muertas llevan por bromurados declives, a un niño cada una.

Y sólo yo me voy quedando, con la diestra, que hace por ambas manos, en alto, en busca de terciario brazo que ha de pupilar, entre mi donde y mi cuando, esta mayoría inválida de hombre.

De forma paradójica, parece que el "terciario brazo" que ha de penetrar la celda tiene que encontrar alguna debilidad en las necesidades férreas del cuerpo. El "dónde" y el "cuándo" definen las limitaciones de Vallejo en el espacio y en el tiempo. De algún modo un brazo incorpóreo y eterno ha de pasar entre los dos, puesto que su "donde" no puede salir de las cuatro paredes de la ceda, y su "cuando" está atrapado entre las dos paredes del tiempo. La palabra "terciario" tiene conexiones evidentes con el número tres en general, y más específicamente con la Trinidad. De este curioso tercer brazo hay precedentes en otros poemas de Trilce. En este planeta poético, mágico, las limitaciones numéricas de este mundo son superadas en una realidad fuera del tiempo y del espacio. En el caso del "terciario brazo" una sugestión de la Trinidad refuerza la posibilidad de una referencia a lo sobrenatural. ${ }^{3}$

La cárcel es el símbolo estático del presente en Trilce, pero hay otros que introducen la naturaleza dinámica del momento. El más humilde de éstos es el carro. Típicamente, Vallejo es arrastrado en el momento (el carro) mirando hacia el pasado (el camino detrás):

Vanse los carros flagelados por la tarde, y entre ellos los míos, cara atrás, a las riendas fatales de tus dedos. (LXXI)

Y la rama del presentimiento se la muerde un carro que simplemente rueda por la calle. (LXVI)

${ }^{3}$ Otros ejemplos de superación son frecuentes en Trilce. Por ejemplo, las palomas del poema $X$ tienen tres alas. 
La primera cita es casi demasiado patenta. $\mathrm{Ni}$ es difícil la segunda: el presentimiento es eliminado poco a poco por el presente, que lo transforma en hechos. Dentro del contexto del poema que menciona la muerte, sospechamos que el presentimiento es de la muerte. Mientras el carro anda, el presentimiento pasa y llega lo que era inminente.

Pero, en Vallejo, el carro es un motivo mucho menos importante que lo que llamaremos la geometría dinámica del tiempo. El presente es un círculo propagándose en el tiempo. En el poema XXX es el ciclo de noche y día: "el circuito / entre nuestro pobre día y la noche grande..." Pero el círculo es más que la mera expresión del ciclo diurno, representa la viciosa monotonía de la vida:

En un auto arteriado de círculos viciosos, torna diciembre qué cambiado, con su oro en desgracia. (XXI)

Vallejo menciona cambios en el poema, pero atribuye la edad de oro al pasado, como siempre. El presente es un círculo vicioso, ineludible:

Cristiano espero, espero siempre de hinojos en la piedra circular que está en las cien esquinas de esta suerte tan vaga a donde asomo. (XXXI)

Como es característico en Vallejo, aqui subraya la dura realidad, petrificándola. Este poema trata de la esperanza: el presente es el círculo al que el poeta expectante está fijado, escudriñando la vaguedad del futuro. Dada la asociación del círculo y el presente que continúa siendo "Lomismo" (II), se transparenta una imagen integrante del poema XXXVI:

Pugnamos ensartarnos por un ojo de aguja enfrentados, a las ganadas.

Amoníacase casi el cuarto ángulo del círculo.

En este poema, que también examina el futuro y la posibilidad, el hombre lucha mirando de frente al futuro. Esta anticipación le va arrancando del presente mientras lucha para completarse. Así, el duro presente se esfuma. El cuarto ángulo del presente que gira casi se convierte en líquido volátil y huidizo. Perọ el "casis" no se puede 
evitar. El hombre no puede remontar su humana condición. Otra vez, como el "terciario brazo", la cifra que no existe pero que lo cambia todo es el ideal de Vallejo: "Sol, herrada su única rueda, quinta y perfecta". (XX) La quinta rueda, que no existe en un carro normal, es perfecta precisamente porque supera la condición del carro. Aunque el sol es tan concreto como un hombre, brilla casi fuera del tiempo.

Sin duda, el conocido poema XLVIII se puede interpretar de manera semejante. Los "soles peruanos" son un juego de palabras. Renglones como "quémase toda y arde llameante, / llameante, / redonda entre mis tímpanos alucinados", nos dejan poca duda del double entendre. La moneda, como el sol, no cambia con el tiempo. Se puede multiplicar inalterada en la mente. En este poema el amontonamiento equivale al tiempo: "acaba por ser todos los guarismos, la vida entera". El círculo de la moneda se puede proyectar mentalmente, sin fin, al pasado y al futuro, como el sol, porque está fuera del tiempo. (Nosotros los humanos, que cambiamos con el tiempo, somos muchos hombres, en vez de un hombre repetido muchas veces en los numerosos presentes del tiempo.)

En Trilic el tema de la multiplicación está íntimamente aliado a la numeración. En efecto, cada presente da luz a un número, que es inmediatamente relegado a una larga lista de números: el pasado. Los números son fechas:

Hitos vagorosos enamoran, desde el minuto montuoso que obstetriza y fecha los amotinados nichos de la atmósfera. (LXIV)

El presente, en este poema, está considerado como solidificación de la posibilidad - la atmósfera amotinada, inconstante, es domada, rotula. da, y tirada a la acumulación del pasado. Una fecha, una hora, representa un momento ya pasado; es el pasado precipitado del mero posible.

Repetidas veces Vallejo imagina una linea geométrica cuando quiere expresar este movimiento del presente que expulsa un pasado continuo detrás de sí:

Canta cerca el verano, y ambos

diversos erramos, al hombro

recodos, cedros, compases unípedos, espartarrados en la sola recta inevitable. (LXVII) 
Por una transposición fácil, la línea se cambia en hilo (con resonancias de los famosos hilos de las Parcas):
La fibra védica,
la lana védica de mi fin final, hilo
del diantre, traza de haber tenido
por las narices
a dos badajos inacordes de tiempo
en una misma campana. (XXXII)

La línea, los hilos, se componen de momentos que son puntos: es el movimiento de un punto que genera una línea. De manera típica, este punto geométrico describe el momento en Trilce: "y a mi siempre en un punto." (XXXIX) En la geometría un punto carece de extensión. Igualmente, el momento y el hombre existiendo en el momento son defin-idos en imágenes que los encogen hasta casi aniquilar su existencia. Por ejemplo:

Quemadura del segundo

en toda la tierra carnecilla del deseo, picadura de ají vagoroso

a las dos de la tarde inmoral. (XXX)

El apetito carnal brota en el momento como un fósforo y rápidamente se apaga. En otra parte, el momento escurridizo está asociado con la existencia brevísima de una gota de agua en la polvareda:

Fósforo y fósforo en la oscuridad.

lágrima y lágrima en la polvareda. (LVI)

Siendo lágrimas, las gotas juntan lo patético a la idea de lo breve que es el momento viviente. Es la brevedad de la pasión y del lamento. Dado esto, podemos sospechar un doble significado en el pasaje siguiente:

Amanece lloviendo. Bien peinada

la mañana chorrea el pelo fino. (LXIII)

La caída uniforme de la lluvia sugiere la espesa sucesión de "bien peinados" instantes. Esta sugerencia está reforzada en el poema LV: 
Vallejo dice hoy la Muerte está soldando

cada lindero a cada hebra de cabello perdido.

Aqui, cada segundo (tan fino como una hebra), inmediatamente perdido, es el lindero del pasado que lo mata y lo absorbe. Así que, de fósforos, a gotas, a hebras, las entrelazadas imágenes de Trilce definen un presente breve, tan breve que es el lindero de la nada. En muchos poemas el presente desaparece completamente y la única realidad que perdura es el pasado.

\section{El Pasado}

Sumergido en una novedad sin novedad, pero círculo tenue y vicioso, Vallejo busca salida en el pasado:

Rumbé sin novedad por la veteada calle que yo me sé. Todo sin novedad, de veras. $Y$ fondée hacia cosas así, y fui pasado. (VII)

Este movimiento, este "ser pasado" simple, es un deseo ferviente en otros poemas. Uno de los motivos preferidos en este atentado de recuperar el pasado es el espejo. Ya hemos visto que para Vallejo mitar hacia atrás equivale a vivir en los recuerdos. Empero, la mirada en el espejo es una imagen más compleja, puesto que mirando para adelante en el espejo (el futuro) el poeta ve lo que está detrás de él (el pasado). El espejo funde delante y detrás en una sola dirección, así que abarcamos los dos "flancos diarios" de un vistazo. Por ejemplo, en el poema VIII:

Pero un mañana sin mañana, entre los aros de que enviudemos, margen de espejo habrá donde traspasaté mi propio frente hasta perder el eco

- y quedar con el frente hacia la espalda.

El momento analizado --un mañana sin mañana- es la muerte del poeta, todavía futura. Cuando él muera será su pasado, su destino. Será 
el espejo mismo, puro reflejo sin futuro (sin delante). La muerte es ser, absolutamente, lo que fue. Por analogía, renunciar al presente $y$ al futuro y ser el pasado acumulado hasta el presente es una muerte más pequeña. Tal muerte se ve claramente en el poema LXVII:

Así yo me decía: Si wendrá aquel espejo que de tan esperado, ya pasa de cristal.

Me acababa la vida, ¿para qué?

Me acababa la vida, para alzarnos sólo de espejo a espejo.

La vida del poeta está perennemente acabándose mientras se alza de momento a momento, de espejo a espejo, mirando hacia delante al pasado. En un espasmo de renunciación (palabra frecuente en Trilce) Vallejo lleva el motivo a su conclusión lógica, y dice que el presente es nada, el pasado es todo. Lo dice a los muertos, en el poema LXXV: "Os digo pues, que la vida está en el espejo, y que vosotros sois el original, la muerte". En sentido estricto tiene razón: la luz que lleva nuestra imagen tarda la mínima fracción de un segundo en su viaje de ida y vuelta, y por consecuencia el yo que vemos es un yo pasado, muerto. Pero ahora, en el contexto de Trilce, la explicación resulta mucho más fácil. Decir que la vida está en el espejo es negarle su propia existencia. El momento-espejo no es más que un agente para la re-creación de las cosas muertas, las originales.

Los conocidos poemas de Los beraldos negros y Trilce que atentan regresar al pasado de Vallejo son un ejemplo notable de la asignación de la realidad al pasado. Los poemas descriptivos, salvo los dedicados a la niñez, desaparecen rápidamente. En Trilce, la forma de los poemas que reflejan el presente es un caos surrealista (muchas veces lo que Leo Spitzer llama "enumeración caótica"). La forma está reflejando el fondo. Sin embargo, la calma de la poesía de Vallejo crece a medida que penetra en el pasado; terminamos con descripciones simples de la vida cotidiana, que sólo escapan a la trivialidad en la tensión irónica, terrible, que sostienen los versos. El poema III es típico. No obstante, no lo podemos fragmentar para nuestro análisis, como lo hemos hecho con los poemas que tratan del presente, porque su efecto depende de una descripción acumulativa en vez de una aglutinación de alucinantes variaciones sobre un tema. Lo copiamos completo:

Las personas mayores

¿a qué hora volverán? 
Da las seis el ciego Santiago, y ya está muy oscuro.

Madre dijo que no demoratía.

Aguedita, Nativa, Miguel, cuidado con ir por ahí, por donde acaban de pasar gangueando sus memorias dobladoras penas, hacia el silencioso corral, y por donde las gallinas que se están acostando todavía, se han espantado tanto.

Mejor estemos aquí no más. Madre dijo que no demoraría.

Ya no tengamos pena. Vamos viendo los barcos ¡el mío es más bonito de todos! con los cuales jugamos todo el santo día, sin pelearnos, como debe ser:

han quedado en el pozo de agua, listos, fletados de dulces para mañana.

Aguardemos así, obedientes y sin más remedio, la vuelta, el desagravio de los mayores siempre delanteros dejándonos en casa a los pequeños, como si también nosotros no pudiésemos partir. Aguedita, Nativa, Miguel? Llamo, busco al tanteo en la oscuridad. No me vayan a haber dejado solo, y el único recluso sea yo.

La austera simplicidad de este poema es sorprendente. Su valor inmediato apenas supera el habla infantil que resuena en los versos. Pero el lector de Vallejo no puede menos que localizar este lenguaje balbuciente en el contexto de su incesante angustia por la familia y el pasado muerto. En este caso el hecho de que sus padres han salido (verdad del pasado) se hace una metonimia que describe el estado del 
poeta en el presente. La salida del pasado simboliza la presente, la permanente salida que es la muerte. La repetida declaración de que la madre no ha de demorarse contradice irónicamente la situación del poeta escribiendo el poema, porque su madre va a demorarse hasta siempre. El último deseo del pasado es anegado por el hecho terrible del presente. Al fin, el poema comunica un irónico contraste entre un pasado-realidad y el presente, tan sutil, tan sin valor, que no es nada.

Los estragos del tiempo están implícitos en los poemas que tratan de la infancia; en muchos otros, el cambio dentro de la vida aparece explícito. Un motivo que lo expresa es el de la desnudez, asociado con el verde paraíso perdido. Así como la pérdida de la inocencia de Adán y Eva fue simbolizada por las hojas que cubrian su desnudez, la caida de Vallejo se expresa con la ropa:

Día que has sido puro, niño, inútil, que naciste desnudo, las leguas

de tu marcha, van corriendo sobre tus doce extremidades, ese doblez ceñudo

de después deshiláchase

en no se sabe qué últimos pañales. (LX)

La analogía con la vida de Vallejo es clara: la niñez es pura y desnuda. Mientras el tiempo corre sobre las doce extremidades (las horas) del día (dos veces, suponemos) se cubre gradualmente de sus "últimos pañales", la mortaja. En este poema las únicas alternativas son la inocencia y la muerte, así como Adán se cubrió de una hoja y luego supo que motiría.

Una imagen parecida es la de calzarse. La "mañana" que se vistió en el poema anterior también nace descalza: "la mañana descalza". (XVII) Puesto que la inocencia es desnudez, la ropa y los zapatos significan la iniciación en una madurez dolorosa e imperfecta: "Arreglo los desnudos que se ajan, se doblan, se harapan." (LVIII) La inocencia se viste de trapos, lo que da relieve a su decadencia. En el poema XX, el motivo del zapato simboliza la transición de la niñez a la experiencia:

el hombre guillermosecundario

puja y suda felicidad

a chorros, al dar lustre al calzado

de su pequeña de tres años. 
Engállase el barbado y frota un lado.

La niña en tanto pónese el índice en la lengua que empieza a deletrear los enredos de enredos de los enredos, y unta el otro zapato, a escondidas, con un poquito de saliba y tierra, pero con un poquito, no má, s.

Esta escena nos presenta la quinta esencia de lo adulto, repleto de barba y dignidad -un hombre activo que imaginamos ser petimetre militar. La niña lleva zapatos, símbolos de su cercana madurez. Su pađre trata de darles el lustro militar, que representan su fe en la sociedad, organización de adultos. Untando su zapato brillante con saliva y tierra, la niña demuestra su conciencia, a lo Vallejo, de lo pobre, lo ajado que es todo vestido. Es significativo que mientras Vallejo sufre, este hombre "guillermosecundario" chorree gozo. Para Vallejo, como para la niña (suponemos), la iniciación en la experiencia no le introduce en un orden perfecto, lustroso y militar, sino en un laberinto de angustia: los enredos de los enredos de los entedos.

El tiempo trae cambios radicales. Crecer es decaer. Nuestro pasado es una altura de que caemos, como Adán de su Edén, su paraiso situado en la cumbre de una montaña: "Se ha degollado una semana con las más agudas caídas." (LXVII) Vallejo clama desde el fondo del presente y se acuerda de las montañas en que nació. El hecho biográfico se hace símbolo: "O valle sin altura madre, donde todo duerme ho. rrible mediatinta, sin ríos frescos, sin entradas de amor". (LXIV) Encarcelado en un presente sin amor, Vallejo mira hacia el pasado. Pero el pasado se acabó:

Se acabó todo al fin: las vacaciones, tu obediencia de pechos, tu manera de pedirme que no me vaya fuera.

Y se acabó el diminutivo, para mi mayoría en el dolor sin fin y nuestro haber nacido así sin causa. (XXXIV) 
Parece que, a pesar de los momentos de esperanza en que el poeta fue pasado, al fin retrocede a un sentimiento de pérdida total. Lo expresa aún más fuertemente en el poema XXXII:

Haga la cuenta de mi vida

o haga la cuenta de no haber aún nacido, no alcanzaré a librarme.

No será lo que aún no haya venido, sino lo que ha llegado y ya se ha ido, sino lo que ha llegado y ya se ha ido.

En estas estrofas el hilo de las Parcas, el total final, la cifra inescapable, las fechas y las horas, todo, suma a nada. Vallejo no puede sumar lo que no ha venido, porque es nada; sólo le queda lo que ha llegado y se ha ido, que es nada. Dos de las tres dimensiones del tiempo vallejiano (LXIV) no son viables para el poeta. Exploremos la dimensión que queda, el futuro.

\section{EL Futuro}

Hijo del pasado y del presente, Vallejo es huérfano. Pero tiene momentos de esperanza para el futuro, y para darle cuerpo muchas veces recurre al color tradicional de la esperanza: "Verde está el corazón de tanto esperar...; Y yo pervivo, y yo que sé plantarme". (LXIV) También piensa en la planta implicada por el color verde, a veces pimpollo, a veces semilla o botón creciendo hacia la posibilidad:

\footnotetext{
Grupo dicotiledón. Oberturan

desde él petreles, propensiones de trinidad

finales que comienzan, ohs de ayes

creyérase avaloriados de heterogeneidad.

¡Grupo de los dos cotiledones! (V)
}

En la palabra dicotiledón Vallejo sucintamente incluye la idea de dos amantes y la de una planta que tiene su fin implícito en su principio. Sin embargo, la esperanza que tantas veces invoca es un sentimiento inestable siempre a punto de derrumbarse. Es el antiveneno contra el miedo y la oscuridad: 
Esperanza plañe entre algodones.

Aristas roncas uniformadas

de amenazas tejidas de esporas magníficas

$y$ con porteros botones innatos.

¿Se luden seis de sol?

Natividad. Cállate, miedo. (XXXI)

Imagen vegetal otra vez: esporas que contienen amenazas en potencia. Vallejo tiene que asegurarse que el futuro que nace contiene la esperanza de la Natividad. Pero no puede ahogar su miedo. No puede imaginar futuro que no sea continuación de su caída, extensión de los mismos círculos viciosos.

Vivir en la esperanza, como vivir en el pasado, no es vivir. El hombre que espera abandona el presente por lo que no existe, aunque sea encantador. De manera característica, unas transparencias incoloras representan esta atrayente falta de existencia en Trilce. El mar es un ejemplo: "Pacífico inmóvil, vidrio, preñado de todos los posibles". (LIX) El cristal es otro motivo parecido:

Este cristal aguarda ser sorbido en bruto por boca venidera sin dientes. No desdentada.

Este cristal es pan no venido todavía.

Este cristal ha pasado de animal, y márchase ahora a formar las izquierdas, los nuevos Menos.

Déjenlo solo no más.

A medida que un hombre vive en potencia, participa de la transparencia de la posibilidad y trasciende el momento animal hacia el momento futuro. Por razones curiosas e indescifrables, Vallejo varias veces habla del pasado a la izquierda. En el poema anterior, la izquierda sin duda implica la expresión popular "un cero a la izquierda". (Vere. mos la frase en el poema que sigue.) El punto del presente se puede considerar un punto decimal, dejando ceros a la izquierda, mientras mueve hacia la derecha; este punto, que es nada, disminuye la cantidad de vida del poeta, y deja nada al otro lado del presente. El tiempo sorbe el cristal que se transforma en su pan de cada día, y mientras el 
futuro se hace pasado el resultado queda en nada. Irónicamente, cuando la posibilidad toma cuerpo es un amontonamiento de ceros, nada más:

Tengo fe en ser fuerte.

Dáme, aire manco, dáme ir

galoneándome de ceros a la izquierda.

Y tú, sueño, dáme tu diamante implacable,

tu tiempo de deshora...

Avíspate la verde bandera presidencial, atriando las seis banderas restantes, todas las colgaduras de la vuelta.

Tengo fe en que soy, $y$ en que he sido menos. (XVI)

Otra vez, en la primera estrofa, la nada se está formando a la izquierda. La proyección de la realidad (aqui un sueño) aparece como el más precioso de la transparencia, el diamante. Dado el contexto pesimista del poema, no es sorprendente encontrar que el sueño es molesto, ya que alcanza su belleza solamente en el reino de la posibilidad. En la próxima estrofa, encontramos el ya conocido verde de la esperanza, aquí una bandera, un desafío. El número siete, la suma de las banderas, generalmente se asocia a la semana en Trilce (v. gr. LXII) Además el lunes, primer día de la semana, significa los comienzos (v. gr. en XV, la esperanza de la resurrección.) El último día de la semana, el domingo, anuncia la muerte en el poema XV y en otros. Alzar la bandera verde, pues, y bajar las seis restantes, es considerar solamente la esperanza de los comienzos e ignorar la inevitable vuelta de la miseria. Y en la última estrofa el conocido "menos" aparece otra vez, idéntico a los ceros de la primera estrofa del poema. Una ironía emana de la última declaración, puesto que lo que es en 'el presente será menos en el próximo instante: habrá sido. El pesimismo de este poema con respecto al futuro es característico en Trilce: lo veremos otra vez en el poema XXXIX, que representa el conflicto del presente ("fósforo, punto, aro") y el futuro ("guias sin color, trascendiente, de frente").

\section{La Poesía y la Existencia}

La esperanza en el futuro es solamente una trascendencia provisoria en el esquema de Vallejo, ya que el futuro, tarde o temprano, se cambiará en presente y pasado. Otros autores han explorado la posibilidad 
de la trascendencia por el arte. Si la vida no da satisfacción, el arte puede recuperar el paraíso verde de la juventud y captarlo en el eterno presente de la perfección. Vallejo es consciente de tal posibilidad y, por lo tanto, participa de la tradición de Baudelaire, Proust, Machado, etc. Pero a diferencia de ellos no puede realmente huir de la vida en la realidad ersatz del esteticismo. El último poema de Trilce trata de la poesía:

Graniza tanto, como para que yo recuerde

y acreciente las perlas

que he recogido del hocico mismo

de cada tempestad.

¿Hasta dónde me alcanzará esta lluvia?

Temo me quede con algún flanco seco; temo que ella se vaya, sin haberme probado en las sequías de increibles cuerdas vocales, por las que para dar armonía, hay siempre que subir ¡nunca bajar!

¿No subimos acaso para abajo? (LXXXVII)

Por todo Trilce las imágenes de agua acompanan al presente vital y al pasado vital (aunque aparecen también en otros contextos). En esta primera estrofa las perlas son los poemas pescados de la fluidez de la experiencia. La aprensión expresada por Vallejo en la segunda estrofa es de que su vitalidad le deje sin mojar la armonía seca de su voz, su verso. La última pregunta (acordémonos que la vida es una caminata para abajo por un declive) quiere saber si el futuro será de verdad mejor que el presente. Así como en San Juan de la Cruz, bajar es subir. Este contraste entre una sequía artística, armónica, y una vitalidad mo. jada se puede ver en el estilo mismo de la poesía. Por un lado, hay su obsesión con las cifras, que tienen evidentes relaciones con la armonía. También, contribuyendo al efecto de armonía, están todos los artificios organizadores que transforman la lengua en poesía. Por otro lado, hay una tendencia al caos, a la irresolución y desorganización que el poeta atribuye a la vida. Cuando escribió Trilce, Vallejo tuvo que contener su sobreabundante vitalidad salvaje para que no se derramase fuera de control. Esta tensión, este equilibrio, es el fondo del poema I: 
Quién hace tanta bulla, y ni deja

testar las islas que van quedando.

Un poco más de consideración

en cuanto será tarde, temprano, y se aquilatará mejor

el guano, la simple calabrina tesórea

que brinda sin querer,

en el insular corazón,

salobre alcatraz, a cada hialóidea

$$
\text { grupada. }
$$

Un poco más de consideración, y el mantillo líquido, seis de la tarde

DE LOS MAS SOBERBIOS BEMOLES.

Y la península párase

por la espalda, abozaleada, impertérrita

en la línea mortal del equilibrio.

La poesía -medio verbal- es sonido bajo uno de sus aspectos. En la primera estrofa hay un contraste entre islas - puestos avanzados de lo seco- en medio de una movilidad fluida que significa ruido, sonido desorganizado. En la segunda estrofa, el "guano" (que es líquido más abajo) se asocia a una "hialóidea grupada", una tempestad verbal. Fluidos vitales militan contra sonidos serenos y armónicos en ambas estrofas. Con un poco de humor itónico Vallejo escribe un renglón en mayúsculas -el equivalente visual del grito; se manda armonizar. (En este caso bemoles significa las armonías de la música.) El renglón mismo es tenso: un equilibrio de ruido y armonía, vida y atte.

El balance mortal del trapecio de Trilce implica una oscilación entre extremos. En el poema LXXIII Vallejo declara que la única verdad está en la dolorida incoherencia ("ay"), y luego, que todo atentado de sintetizar vida y armonía es absurdo:

Tengo pues derecho

a estar verde y contento y peligroso, y a ser

el cincel, miedo del bloque basto y vasto;

a meter la pata y a la risa, 


\begin{abstract}
Absurdo, sólo tú eres puro.
Absurdo, este exceso sólo ante ti se suda de dorado placer.
\end{abstract}

Ya hemos encontrado el "verde" y el "estar bien"; esto se contrasta con el arte, al cincelar formas en el bloque basto y vasto de la vida. Al fin del análisis no encontramos vida ni arte solos, sino más bien la síntesis contradictoria de los dos: el equilibrio.

El equilibrio de Trilce no es de giroscopio. En esta visión terrible no cabe esperanza sin desesperación. El motivo de lo doble, lo quebrado, lo ambigur, es el que más se repite en el libro. Aunque el presente tenga su atracción, es fugaz, agonizante, y al fin, nada (punto, cero, aquí mismo). Aunque el pasado nos dé alivio en nuestro presente insoportable, está muerto, y finalmente, es nada (cero a la izquierda). Aunque el futuro ofrezca la esperanza de una vida mejor, de desahogo, es por definición nada (cero a la derecha). Y cuando el futuro es pasado, otra vez es nada. Además, el arte no ofrece ninguna solución. Ultimamente no hay vida viable en Trilce. Hay existencias hipotéticas presentadas como posibilidades, pero todas se aniquilan en sus contradicciones; la nada es la única posibilidad no contradicha. Trilce es una metafísica de la indecisión, grito imposible del poeta existiendo en un punto inexistente, entre ceros.

Mas si se ha de sufrir de mito a mito, y a hablarme llegas masticando hielo, mastiquemos brasas, ya no hay donde bajar, ya no hay donde subir.

Se ha puesto el gallo incierto, hombre. (XIX)

John Caviglia 
